\title{
Infeksi Cacing Usus Soil Transmitted Helminths Terhadap Kebiasaan Mencuci Tangan pada Siswa SD
}

\section{Helminths Transmitted Soil Intestinal Infection Against Hand Washing Habits in Elementary Students}

\author{
AGNESHA LUSIANA TIFANNOV \\ Jurusan Analis Kesehatan Poltekkes Kemenkes Semarang \\ Jl. Wolter Monginsidi Pedurungan Tengah Semarang \\ E-mail:agnesalusiana@gmail.com
}

\begin{abstract}
Abstrak
Infeksi cacing usus yang ditransmisikan melalui tanah (Soil Transmitted Helminths, STH) yang terdiri dari Ascaris lumbricoides, Trichuris trichiura, dan cacing tambang, masih sering ditemukan dimasyarakat. Penyebaran infeksi cacing usus STH terjadi apabila adanya kontak dengan tanah yang terkontaminasi telur cacing, sehingga kebiasaan mencuci tangan memiliki peran dalam terjadinya infeksi. Tujuan penelitian ini untuk mengetahui hubungan pencemaran angka kejadian infeksi cacing usus Soil Transmitted Helminths dengan kebiasaan mencuci tangan siswa di SD Islam Taqwiyatul Wathon. Merupakan penelitian analitik observasional dengan pendekatan cross sectional. Jumlah sampel 92 feses siswa SD Islam Taqwiyatul Wathon yang telah mengisi kuesioner. Analisis data dilakukan menggunakan uji statistik Chi-Square Test dengan tingkat kemaknaan 95\% dan $\alpha(0,05)$. Hasil menunjukkan 7 siswa (8\%) terinfeksi dan 85 siswa (92\%) tidak terinfeksi kecacingan, dengan infeksi Ascaris lumbricoides terbanyak yaitu sebanyak 4 (4\%) orang siswa. Pada uji Chi-Square diketahui terdapat hubungan yang bermakna antara kebiasaan mencuci tangan dengan angka kejadian infeksi kecacingan $(p=0,018)$. Ada hubungan yang bermakna antara kebiasaan mencuci tangan dengan angka kejadian infeksi cacing usus Soil Transmitted Helminths pada siswa SD Islam Taqwiyatul Wathon tahun 2018.
\end{abstract}

Kata Kunci: Kebiasaan mencuci tangan ; infeksi telur cacing Soil Transmitted Helminths.

\begin{abstract}
Intestinal worm infection caused by soil-transmitted helminthes that consists of Ascaris lumbricoides, Trichuris trichiura, and hookworm, still can be found in population. soil-transmitted helminthes infection happens by contacting with soil that is infected by worm eggs, so the hand washing having have important role inspreading an infection. Purpose of the study to know relationship of association between soil-transmitted helminthes (STH) infection and hand washing habits in students of Taqwiyatul Wathon Islamic Elementary School. This research is analytic observational research with the approach of cross sectional, there are 92 samples of the students of Taqwiyatul Islamic Elementary School who had filled questionnaire. Analysis of data committed using statistics chi-square test with a level of signification $95 \%$ and $\alpha(0.05)$. The results show 7 students (8\%) were infected, and 85 students (92\%) were not infected. Most infection was caused by Ascaris lumbricoides, and was found in 4 (4\%). The Chi-Square Test showed there is significant difference between the habits handwashing with the number of soil-transmitted helminthes infection ( $p=0,018)$. There is a relationship between the habits handwashing with the number of soil-transmitted helminthes infection students of Taqwiyatul Wathon Islamic Elementary School.
\end{abstract}

Keyword: Habits handwashing ; Infection of Soil Transmitted Helminths. 


\section{Pendahuluan}

Penyakit kecacingan adalah penyakit yang disebabkan masuknya parasit (berupa cacing) ke dalam tubuh manusia. Jenis cacing yang sering ditemukan menimbulkan infeksi adalah cacing gelang (Ascaris lumbricoides), cacing cambuk (Trichuris trichuria) dan cacing tambang (Ancylostoma duodenale dan Necator americanus) yang ditularkan melalui tanah (Soil Transmitted Helminths atau STH). Infeksi cacing ini dapat mengakibatkan terjadinya anemi, gangguan gizi, gangguan pertumbuhan dan gangguan kecerdasan. Dalam jangka panjang apabila terjadi infeksi secara terus menerus akan menurunkan kualitas sumber daya manusia (Ghasasani, 2011; WHO, 2009).

Berdasarkan survey yang dilakukan ditemukan bahwa pada golongan usia anak sekolah sekolah dasar prevalensi kecacingan cukup tinggi, yakni berkisar $60 \%-80 \%$ (Depkes RI, 2006). Prevalensi kecacingan di Jawa Tengah tahun 2004-2009 sebesar 4,37\%. Tingkat higiene perorangan yang rendah dan penularan dari teman sekolah / bermain merupakan faktor penyumbang angka infeksi (Purnamasari, 2017). Berdasarkan data dari Dinas Kesehatan Kota Semarang presentasi angka penyakit cacingan pada anak usia sekolah (5-14 tahun) mengalami penurunan. Pada tahun 2010 di Kelurahan Bandarharjo Kecamatan Semarang Utara terdapat 54 jumlah anak dari 142 jumlah orang yang terinfeksi penyakit cacing (38\%) dan pada tahun 2011 terdapat 34 jumlah anak dari 113 jumlah orang yang terinfeksi penyakit cacing (30\%). (Purnamasari, 2017)

Berdarkan hasil observasi lapangan di SD Islam Taqwiyatul Wathon, lokasi tersebut dekat dengan pelabuhan Tanjung Mas, setiap hari mulai jam setengah enam pagi dan jam empat sore terjadi rob, jalanan yang belum beraspal, iklim yang lembab, mayoritas murid SD Islam Taqwiyatul Wathon tinggal tidak jauh dari sekolah dan para muridnya juga kurang mengenal tentang perilaku hidup bersih dan sehat (PHBS). Kebanyakan siswanya berkuku panjang dan tidak terawat sehingga memiliki risiko penularan terinfeksi telur cacing STH karena penularannya dapat dari tangan ke mulut, serta kebiasaannya yang tidak membiasakan mencuci tangan dahulu sebelum mereka mengkonsumsi makanan jajanan karena telur cacing STH dapat masuk ke dalam perut melalui jari-jari tangan mereka yang dimasukkan ke dalam mulut. Berdasarkan uraian diatas, peneliti tertarik untuk melakukan penelitian angka kejadian infeksi cacing usus STH (Soil Transmitted Helminths) berhubungan dengan kebiasaan mencuci tangan pada salah satu sekolah dasar yang terletak di wilayah pemukiman padat di daerah Semarang.

\section{Metode}

Jenis penelitian yang digunakan adalah penelitian observasional analitik dengan pendekatan cross Sectional. Populasi dalam penelitian ini adalah siswa kelas 4 dan 5 SD Islam Taqwiyatul Wathon, Kelurahan Tanjung Mas, Semarang Utara. Subjek penelitian ini adalah siswa SD Islam Taqwiyatul Wathon dan bersedia menjadi subjek penelitian. Data yang dikumpulkan adalah data primer, yaitu : Data sampel yang diambil melalui inform concent dan kuesioner, data hasil pemeriksaan infeksi cacing Soil Transmitted Helminths yang diperiksa di Laboratorium Klinik Analis Kesehatan Poltekkes Kemenkes Semarang. Data yang terkumpul diolah untuk mengetahui hubungan antara kebiasaan mencuci tangan dengan angka kejadian infeksi cacing usus Soil Transmittsd Helminths di SD Islam Taqwiyatul Wathon maka dilakukan uji statistik yaitu uji Chi-Square dengan menggunakan SPSS 16. Menggunakan dengan derajat kepercayaan 95\% $(0,05)$. 


\section{Hasil dan Pembahasan}

\section{a. Analisis Univariat}

Tabel 1 Hasil Responden

\begin{tabular}{ccccc}
\hline No & & Kecacingan & Frekuensi & $\%$ \\
\hline 1 & Positif & & 7 & 8 \\
2 & Negatif & Total & 85 & 92 \\
\hline \multicolumn{2}{r}{} & \multicolumn{2}{c}{92} & 100 \\
\hline
\end{tabular}

Berdasarkan hasil pemeriksaan dilaboratorium, dari 92 sampel yang diperiksa sebanyak 7 murid terinfeksi telur cacing STH dengan persentase $8 \%$ dan 85 murid yang tidak terinfeksi telur cacing STH dengan persentase $92 \%$.

Tabel 2 Jenis Infeksi

\begin{tabular}{clcc}
\hline No & \multicolumn{1}{c}{ Kecacingan } & Frekuensi & $\%$ \\
\hline 1 & Ascaris lumbricoides & 4 & 57 \\
2 & Trichuris trichiura & 2 & 29 \\
3 & Cacing tambang & 1 & 14 \\
\hline & Total & 7 & 100 \\
\hline
\end{tabular}

Berdasarkan hasil pemeriksaan ditemukan 7 sampel yang positif telur cacing STH dengan jenis telur cacing Ascaris lumbricoides dengan persentase 57\%, Trichuris trichiura dengan persentase $29 \%$, dan cacing tambang dengan persentase $14 \%$.

Tabel 3 Kebiasaan Mencuci Tangan

\begin{tabular}{clccc}
\hline No & & Kecacingan & Frekuensi & $\%$ \\
\hline 1 & Buruk & & 26 & 28 \\
2 & Baik & & 66 & 72 \\
\hline \multicolumn{2}{r}{} & Total & 92 & 100 \\
\hline
\end{tabular}

Berdasarkan hasil kuesioner kebiasaan mencuci tangan murid pada siswa SD Islam Taqwiyatul Wathon secara garis besar sudah baik. Tabel diatas menunjukkan bahwa 66 murid dengan persentase $72 \%$ telah memiliki kebiasaan mencuci tangan yang baik, sementara 26 murid dengan persentase $28 \%$ yang memiliki kebiasaan mencuci tangan yang buruk.

\section{b. Analisis Bivariat}

Tabel 4 Tabel Tabulasi Silang antara Kebiasaan Mencuci Tangan dengan infeksi cacing usus Soil Transmitted Helminths pada Siswa SD Islam Taqwiyatul Wathon, Kelurahan Tanjung Mas, Semarang Utara pada Bulan April 2018

\begin{tabular}{|c|c|c|c|c|c|c|c|}
\hline \multirow{3}{*}{$\begin{array}{c}\text { Kebiasaan } \\
\text { mencuci } \\
\text { tangan }\end{array}$} & \multicolumn{4}{|c|}{ Kecacingan } & \multirow{2}{*}{\multicolumn{2}{|c|}{ Total }} & \multirow{3}{*}{$\begin{array}{c}\text { P Value } \\
\text { (Chi-Sq } \\
\text { uare } \\
\text { Test) }\end{array}$} \\
\hline & \multicolumn{2}{|c|}{ Positif } & \multicolumn{2}{|c|}{ Negatif } & & & \\
\hline & $\mathrm{N}$ & $\%$ & $\mathrm{~N}$ & $\%$ & $\mathrm{~N}$ & $\%$ & \\
\hline Buruk & 5 & 5,43 & 21 & 22,82 & 26 & 28,26 & \\
\hline
\end{tabular}




\begin{tabular}{ccccccc} 
Baik & 2 & 2,17 & 64 & 69,56 & 66 & 71,74 \\
\hline Total & 7 & 7,6 & 85 & 92,38 & 92 & 100 \\
\hline
\end{tabular}

Data pada tabel 4 menunjukkan bahwa dari 26 responden yang memiliki kebiasaan mencuci tangan yang buruk ditemukan 5 responden yang mengalami infeksi kecacingan, sedangkan dari 66 responden yang memiliki kebiasaan mencuci tangan yang baik, terdapat 2 responden yang mengalami infeksi kecacingan. Hasil analisis dengan menggunakan uji chi-square test di peroleh nilai $\mathrm{p}$ sebesar 0,018 , dapat disimpulkan terdapat hubungan yang bermakna antara kebiasaan mencuci tangan dengan infeksi kecacingan.

\section{Simpulan dan Saran}

\section{Simpulan}

Siswa yang terinfeksi cacing usus STH sebanyak 7 siswa dengan angka infeksi kecacingan sebesar $8 \%$. Sebagian besar siswa tergolong dengan kebiasaan mencuci tangan baik (71,74\%), sementara 28,26\% tergolong dengan kebiasaan mencuci tangan buruk. Ada hubungan yang bermakna antara kebiasaan mencuci tangan dengan angka kejadian infeksi cacing usus Soil Transmitted Helminths.

\section{Saran}

Siswa sebaiknya mulai membiasakan diri hidup bersih dan sehat untuk diterapkan di kehidupan sehari-hari, salah satunya dengan mencuci tangan setelah bermain di tanah, setelah buang air besar, mencuci tangan sebelum makan dan setelah memegang binatang untuk pencegahan infeksi cacingan. Siswa yang positif terinfeksi kecacingan akan diberikan obat cacing.

\section{Daftar Pustaka}

Alfath, Salman. (2010). Insidensi Infeksi Soil Transmitted Helminths pada Siswa SDN 13 Siantan Hilir kecamatan Pontianak Timur Kotamadya Pontianak Tahun 2014. Skripsi, Universitas Tanjungpura, Pontianak

Departemen Kesehatan RI. (2006). Buku Pedoman Nasional Pemberantasan Penyakit Cacingan

Dharma, Yudha Prasetyo. Hubungan Faktor Sosio-Ekonomi dan Tingkat Pengetahuan Orang Tua Dengan Kejadian Infeksi Soil Transmitted helminth (STH) dan Pemetaan Tempat TInggal Siswa terinfeksi STH Pada Siswa SDN 1 Krawangsari Natar, Skripsi, Fakultas Kedokteran Universitas Lampung, Lampung. (2016). diunduh 24 Agustus 2017 pada http://digilib.unila.ac.id/21774/3/SKRIPSI\%20\%20TANPA\%20BAB\%20PEMBAHAS AN.pdf

Gandahusada,S., Herry D.I,Wita Pribadi. (1998). Parasitologi Kedokteran, Edisi ke-3. Jakarta: balai penerbit FKUI

Gandahusada., Srisasi. (2002). Parasitologi Parasitologi Kedokteran. Edisi ketiga. Jakarta: FKUI

Gandahusada, S., Ilahude H, Herry D, dan Pribadi, W. (2003). Parasitologi Kedokteran Edisi ke-3. Jakarta: FKUI

Gandahusada, S., Ilahude, H.H., dan Pribadi, W. (2006). Parasitologi Kedokteran Edisi ke-3. Jakarta: FKUI

Ghassani, Atika. Hubungan Infeksi Cacing Usus STH Dengan Kebiasaan Bermain Tanah Pada SDN 09 Pagi Paseban Tahun 2010, Skripsi, FKUI, Jakarta. (2011). dari http://lib.ui.ac.id/file?file=digital/20355046-S-Atika\%20Ghassani.pdf 
Hadidjaja. (2002). Atlas Parasitologi Kedokteran. Jakarta : Gramedia Pustaka Utama

Lestari, T,W. (2014). Hubungan Tingkat Pengetahuan, Sikap dan Perilaku Pencegahan Siswa SDN 3 Pontianak Timur Kotamadya Pontianak tahun 2014. Skripsi, Fakultas Kedokteran Universitas Tanjungpura, Pontianak

Oktavia, Nanda. Hubungan Infeksi Cacing Usus Soil Transmitted Helminths Dengan Kebiasaan Mencuci Tangan Pada Siswa SDN 09 Pagi Paseban Tahun 2010, Skripsi, FKUI, Jakarta. (2011) diunduh pada tanggal 7 September 2017 dari http://www.google.co.id/url?sa=t\&rct=j\&q=\&esrc=s\&source=web\&cd=1\&ved=0ahUK Ewjymdzk3sPYAhUaSI8KHeP DBUQFggmMAA\&url=http\%3A\%2F\%2Flib.ui.ac.id\% 2Ffile\%3Ffile\%3Ddigital\%2F20320015-S-Nanda\%2520Oktavia.pdf

Onggowaluyo, J.S. (2002). Parasitologi Medik I (Helmintologi). Jakarta : EGC

Purnamasari, Dewi. (2017). Hubungan Higiene Dan Sanitasi Terhadap Infeksi Telur Cacing Kremi (Enteribius vermicularis) Pada Murid Kelas 1 SD Islam Taqwiyatul Wathon Kelurahan Tanjung Mas Kecamatan Semarang Utara. Karya Tulis Ilmiah. Poltekkes Semarang.

Putri, Adinda Riski Purnaning. (2015). Hubungan Pencemaran Telur Soil Transmitted Helminths Di Tanah Halaman Rumah Dengan Infeksi Kecacingan Pada Anak Usia 5-12 Tahun Di RT.6 RW.5 Desa Menduran Kecamatan Brati Kabupaten Grobogan, Karya Tulis Ilmiah, Poltekkes Semarang, Semarang.

Sastroasmoro, Sudigdo., Sofyan Ismael. (2010). Dasar-dasar Metodologi Penelitian Klinis, Edisi ke-3. Jakarta: Sagung Seto

Soedarto. (1991). Helmontologi Kedokteran. Jakarta : EGC

Soedarto. (2009). Pengobatan Penyakit Parasit Amubiasis Malaria, Cacing Tambang, Filariasis, dan Penyakit Parasit Lainnya. Jakarta: CV. Agung Seto

Soedarto. (2011). Buku Ajar Parasitologi Kedokteran. Jakarta: CV Sagung Seto

Sofiana, L. (2011). Hubungan Perilaku dengan Infeksi Soil Transmitted Helminths pada Anak Sekolah Dasar MI Asas Islam Kalibening Salatiga. Skripsi, Fakultas Kesehatan Masyarakat, Yogyakarta

World Health Organization (WHO). Worm Disease: Guidelines For Diagnosis, Treatment, Prevention And Control. (2009). http://www.who.int/research diakses pada 19 Desember 2014

Zulkoni. (2011). Parasitologi untuk Keperawatan, Kesehatan Masyarakat, Teknik Lingkungan. Yogyakarta: Nuha Medika 